\title{
Occurrence of Squash yellow mild mottle virus and Pepper golden mosaic virus in Potential New Hosts in Costa Rica
}

\author{
Ruth M. Castro ${ }^{1,2 *}$, Lisela Moreira ${ }^{2,3}$, María R. Rojas ${ }^{4}$, Robert L. Gilbertson ${ }^{4}$, Eduardo Hernández ${ }^{2}$, \\ Floribeth Mora ${ }^{2,5}$ and Pilar Ramírez ${ }^{2,6}$ \\ ${ }^{1}$ Escuela de Ciencias Agrarias, Universidad Nacional, Heredia, Costa Rica \\ ${ }^{2}$ Centro de Investigación en Biología Celular y Molecular, Universidad de Costa Rica, CP 11501-2060, San Jose, Costa Rica \\ ${ }^{3}$ Escuela de Agronomía, Universidad de Costa Rica, San Jose, Costa Rica \\ ${ }^{4}$ Plant Pathology Department, University of California-Davis, California, USA \\ ${ }^{5}$ Servicio Fitosanitario del Estado, Convenio UCR-MAG \\ ${ }^{6}$ Escuela de Biología, Universidad de Costa Rica, San Jose, Costa Rica
}

(Received on December 4, 2012; Revised on February 12, 2013; Accepted on March 13, 2013)

Leaf samples of Solanum lycopersicum, Capsicum annuum, Cucurbita moschata, Cucurbita pepo, Sechium edule and Erythrina spp. were collected. All samples were positive for begomoviruses using polymerase chain reaction and degenerate primers. A sequence of $\sim 1,100$ bp was obtained from the genomic component DNA-A of 14 samples. In addition, one sequence of $\sim 580$ bp corresponding to the coat protein (AV1) was obtained from a chayote ( $S$. edule) leaf sample. The presence of Squash yellow mild mottle virus (SYMMoV) and Pepper golden mosaic virus (PepGMV) were confirmed. The host range reported for SYMMoV includes species of the Cucurbitaceae, Caricaceae and Fabaceae families. This report extends the host range of SYMMoV to include the Solanaceae family, and extends the host range of PepGMV to include C. moschata, C. pepo and the Fabaceae Erythrina spp. This is the first report of a begomovirus (PepGMV) infecting chayote in the Western Hemisphere.

Keywords : begomovirus, vegetables, whiteflies

Latin America and the Caribbean Islands posses a great diversity and incidence of begomoviruses (Morales, 2010). Since 1950, weeds of the Euphorbiaceae (Costa and Bennett, 1950) and Malvaceae (Costa and Carvalho, 1960) families have been identified as primary sources of inoculum for the transfer of these viruses to nearby crops. However, it was not until the 1970s that the first important losses in production due to viral infections caused by this group of pathogens were reported in crops such as cotton (Gossypium hirsutum and G. barbadense) and bean (Phaseolus vulgaris) (Morales, 2010).

The genus Begomovirus (Geminiviridae) is characterized

\footnotetext{
*Corresponding author.

Phone) +506-2277-3296, FAX) +506-2261-0035

E-mail) ruth.castro.vasquez@una.cr
}

by a circular single-stranded DNA genome, encapsidated in twinned icosahedral particles. Begomoviruses of New World have bipartite genomes. The DNA-A component include several open reading frames (ORFs) related to replication, encapsidation, movement and transcriptional activation of virion sense genes (Harrison, 1985). The DNA-B component has two ORFs implicated in viral systemic movement (Etessami et al., 1988).

The begomoviruses are recognized as infectious agents causing economic losses in crops in tropical and subtropical zones worldwide (Dhaliwal et al., 2010; Navas-Castillo et al., 2011; Rojas et al., 2005). An important group of begomoviruses in America are those infecting cucurbits. Among the most prominent are Squash leaf curl virus (SLCV), Squash mild leaf curl virus (SMLCV), Cucurbit leaf crumple virus (CuLCrV), Squash yellow mild mottle virus (SYMMoV) and Melon chlorotic leaf curl virus (MCLCuV) which cause economic losses in Cucurbita moschata, C. pepo, C. maxima, Cucumis melo and Citrullus lanatus (Idris et al., 2008; Karkashian et al., 2002; Morales, 2010). Since these viruses can infect the same plant host species, mixed infections have been found in which rearrangements are formed by the encapsidation of DNA-A of one virus species with DNA-B of a different virus species. The degree of virulence depends on the species that are mixed and on the host plant (Idris et al., 2008).

In the Western Hemisphere, the first reports of begomoviruses in pepper (Capsicum spp.) crops were in the United States (Brown et al., 1989; Brown and Poulos, 1990) and Mexico (Leal and Quintero, 1989). Currently, Pepper golden mosaic virus (PepGMV) is one of the most important species (Brown et al., 2005) affecting Capsicum annum (bell pepper), with a host range that also includes Solanum lycopersicum (tomato) (Nakhla et al., 1994; 2005; Rojas et al., 2000; 2005) and some cucurbits (Ala-Poikela et al., 2005). Other viruses detected in pepper as well as tomato 
include Pepper huasteco yellow vein virus (PHYVV) (Morales et al., 2005), Tomato leaf curl Sinaloa virus (ToLCSinV) (Brown et al., 1993), Tomato severe rugose virus (ToSRV) (Bezerra-Agasie et al., 2006; Nozaki et al., 2006), Tomato yellow leaf curl virus (TYLCV) (AscencioIbáñez et al., 1999; Quiñones et al., 2001) and Potato yellow mosaic virus (PYMV) (Umaharan et al., 1998).

Begomoviruses identified in Costa Rica to date include PepGMV in pepper (Lotrakul et al., 2000) and tomato (Nakhla et al., 2005), ToLCSinV (Idris et al., 1999; Nakhla et al., 2005) and Tomato yellow mottle virus (ToYMoV) (Hilje et al., 1993; Nakhla et al., 1994) in tomato. Squash yellow mild mottle virus (SYMMoV) has been detected in Cucurbita moschata (squash), Citrullus lanatus (watermelon), Carica papaya (papaya) (Karkashian et al., 2002) and bean (Karkashian et al., 2011). There are also reports of PepGMV (Hilje et al., 1993), Bean golden mosaic virus (BGMV) (Gámez, 1971) and Calopogonium golden mosaic virus (CaGMV) (Díaz et al., 2002) in bean.

The Cartago province, one of the most important areas of vegetable production in Costa Rica, has been studied continuously. Research in this region has shown the possibility of an amplified host range for these viruses and the potential emergence of new virus species from the recombination of existing species.

The objectives of this research were to identify and determine the sequence variability of begomoviruses in Cartago in tomato, pepper, squash, Cucurbita pepo (zucchini, scaloppini), Sechium edule (chayote) and Erythrina spp., and to determine phylogenetic relationships between these and previously described sequences.

\section{Materials and Methods}

Sample collection and total nucleic acid extraction to obtain begomovirus DNA. A total of 15 leaf samples from tomato, pepper, cucurbits and Erythrina spp. were collected in the Cartago province in 2007 and 2008. Samples were stored at $-70^{\circ} \mathrm{C}$. The protocol described by Dellaporta et al. (1983) was followed to obtain total nucleic acid.

Rolling circle amplification (RCA) and polymerase chain reaction (PCR) for detection of begomoviruses. Total DNA purified from 15 leaf samples were amplified by RCA (Fire and $\mathrm{Xu}, 1995)$ using the Ilustra ${ }^{\mathrm{TM}}$ TempliPhi Amplification Kit (GE Healthcare, UK). RCA products were reamplified by PCR using degenerate primers AV494 and AC1048 (Wyatt and Brown, 1996) for the core of capsid protein gene (AV1) to confirm the presence of begomovirus infection. The final volume of the reactions was $25 \mu \mathrm{l}$ containing: $1 \times$ reaction buffer, $2.5 \mathrm{mM} \mathrm{MgCl} 2,250 \mu \mathrm{M}$ dNTPs, $0.1 \mu \mathrm{M}$ each primer, 5U/ $\mu \mathrm{l}$ Dream Taq DNA polymerase (Fermentas, Hanover, MD) and $2 \mu$ l viral DNA amplified by RCA. The PCR program used the conditions defined by Rojas et al. (1993).

PCR for molecular characterization of begomoviruses. RCA products of 14 samples were reamplified by PCR using degenerate primers PAC1C1960 and PAV1v722 (Zhou et al., 1997), which correspond to a region of $\sim 1300$ bp of the DNA-A. This region will be referred herin as DNA-A bottom and it includes complete nucleotide sequences of the replication enhancer protein (AC3) and transcriptional activator protein (AC2). Additionally, the amplicon also contains a partial sequence of the replication associated protein (AC1) and coat protein (AV1) genes. PCR reactions were carried out as described previously by Rojas et al. (1993).

Electrophoretic analysis. RCA and PCR products were analyzed by electrophoresis in TopVision $1 \%$ agarose gels (Fermentas) in $1 \times$ TAE buffer at $100 \mathrm{~V}$ for $40 \mathrm{~min}$. The O'GeneRuler $^{\mathrm{TM}} 100$ bp Plus DNA Ladder and the O'RangeRuler 500 bp DNA Ladder (Fermentas) were used as molecular weight markers. The amplicons were stained with ethidium bromide $(1 \mathrm{mg} / \mathrm{ml})$ in water, visualized with ultraviolet light (TFX-20.M, Vilber Lourmat), and photographed with a digital camera (Kodak EDAS 290).

Sequencing and phylogenetic analysis. The DNA-A bottom from the 14 previously amplified isolates and the AV1 gene from the Cha157 was sequenced. Sequencing was carried out with a BigDye Terminator 3.1v (Applied Biosystems, Foster City, CA) and the automated sequencer Genetic Analyzer 3130, AB (Applied Biosystems, USA). The BLASTn algorithm (Altschul et al., 1990) was used to compare nucleotide sequences of the amplified PCR products with sequences available in the GenBank database. The sequences of the 15 samples begomovirus-positive samples obtained in this study and those from GenBank that shared the greatest nucleotide identity with our samples,were aligned using the Clustal W algorithm (Thompson et al., 1994). Phylogenetic trees were constructed with the MEGA program version 5 (Kumar et al., 2008), using the nucleotide distances obtained and neighbor-joining phylogenetic analysis (Kimura, 1980). Internal branch robustness was estimated by bootstrap analysis with 1000 replicates.

\section{Results}

The symptoms observed in plants infected with begomoviruses in this study included yellow mosaic, yellow veins, changes in leaf size and morphology, leaf thickening, thickened vein, and yellow wrinkled leaf margins (Fig. 1). 

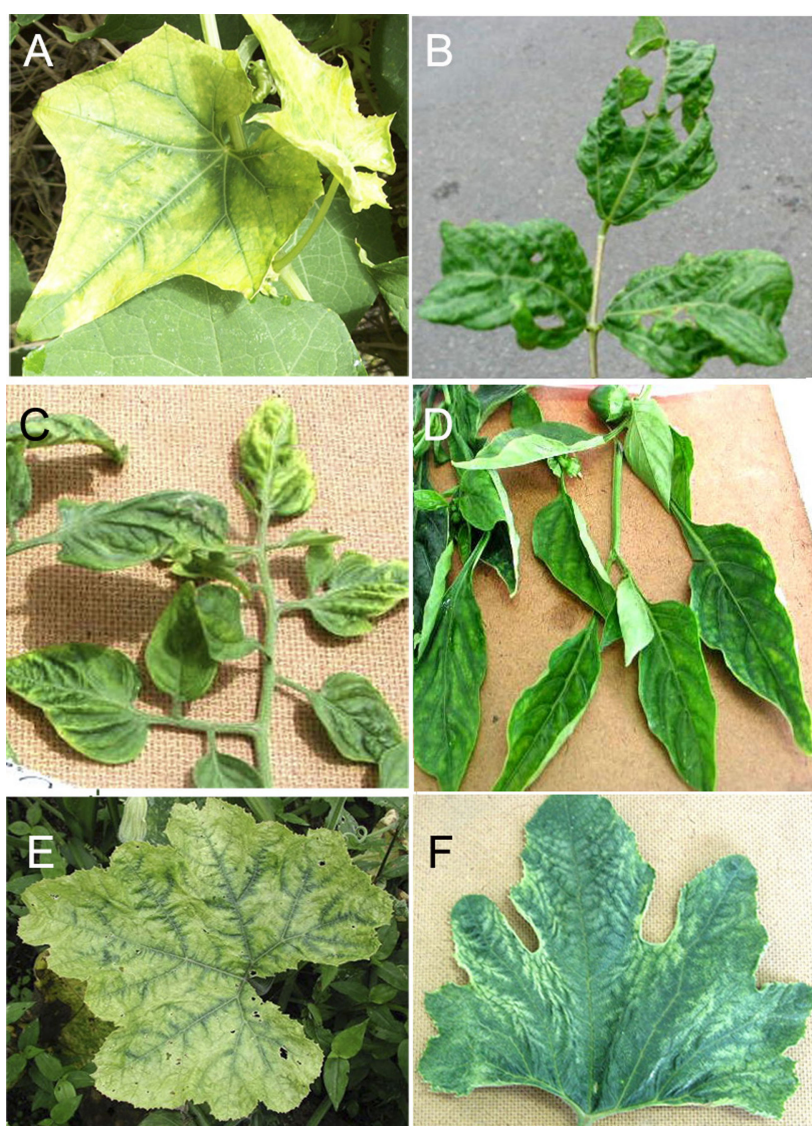

Fig. 1. Symptoms in (A) Sechium edule (chayote), (B) Erythrina spp. (poro), (C) Solanum lycopersicum (tomato), (D) Capsicum annuum (bell pepper), (E) Cucurbita moschata (squash) and (F) Cucurbita pepo (scallopini), infected with whitefly-transmitted viruses.

Symptomatic leaf samples detected with begomovirus were collected from tomatoes, peppers, cucurbits and Erythrina spp. In addition, begomovirus infection was detected in one asymptomatic zucchini sample.

RCA products of 14 samples reamplificated by PCR using primers targeted to the DNA-A bottom of the viral genome yielded products circa $1,300 \mathrm{bp}$ for all samples (Fig. 2). These 14 amplicons and the amplicon corresponding to the coat protein (AV1 gene) from the chayote leaf sample (Cha157) were sequenced. Sequences of $\sim 1,100 \mathrm{bp}$ were obtained from the genomic component DNA-A of the 14 samples and one sequence of $\sim 580 \mathrm{bp}$ corresponding to the AV1 gene was obtained from Cha157 sample.

The presence of SYMMoV or PepGMV was confirmed in those 15 samples. Seven sequences shared high similarity with SYMMoV (Table 1); and the remaining eight sequences were similar to PepGMV (Table 2). Only seven out of the latter eight sequences are shown in Table 2, because only the sequence corresponding to the capsid protein (AV1 gene) was obtained for sample Cha157. Nevertheless, the AV1 gene region is also useful for the preliminary identification of a virus species (Brown et al., 2001a). The nucleotide differences between these 15 isolates and other viral sequences obtained from the NCBI GenBank database were not clustered into particular regions of the DNA-A bottom or $\mathrm{AV} 1$ gene sequence.

The sequences similar to SYMMoV were from cucurbit samples and two were from solanaceous hosts (tomato and pepper). The sequence of the DNA-A bottom region (Table 1) shared $96-97 \%$ similarity with SYMMoV (GenBank, AY064391) and $89-90 \%$ with MCLCuV-GT (GenBank, AF325497). Four of the PepGMV sequences were from cucurbit samples, three were from pepper and one was from Erythrina spp. (Fabaceae). Sequences of the DNA-A bottom region (Table 2) shared $97-99 \%$ identity with PepGMVCR (GenBank, AF149227) and 95 - 97\% with PepGMVSer (GenBank, AY928516). The capsid protein gene sequence (AV1, 580 bp) from the chayote sample Cha157 shared
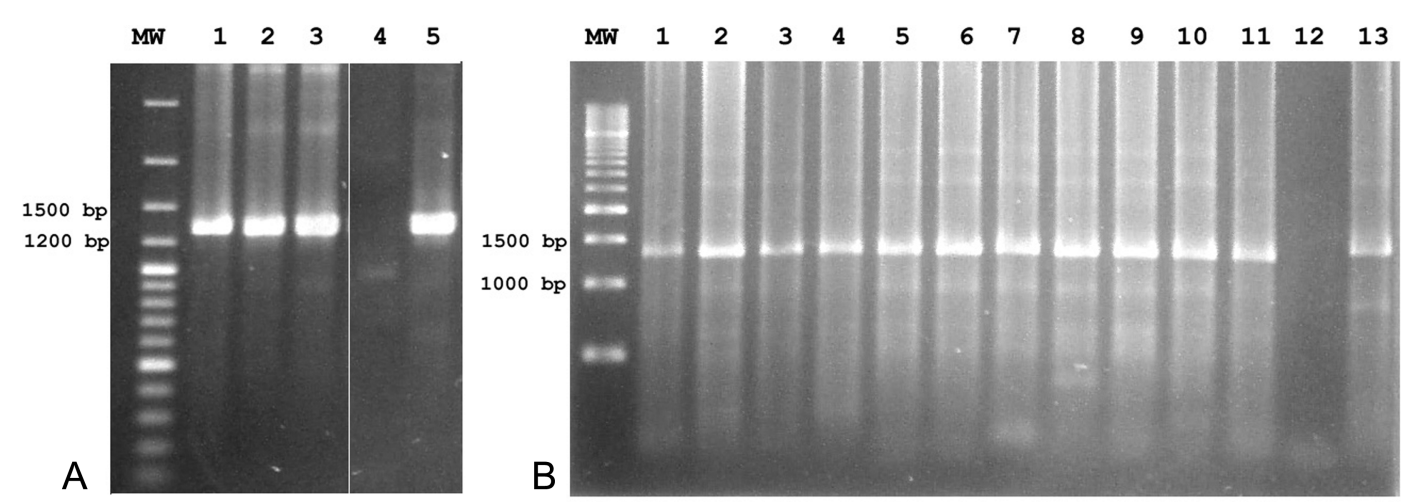

Fig. 2. PCR analysis from 14 RCA products performed with the degenerate primers PAC1C1960 and PAV1v722, which correspond to a partial DNA-A sequence. (A) (MW) contains a 100 bp DNA size marker, samples Po3696, Cha4265, Sq229 (Lane 1 - 3), negative control (Lane 4) and positive control a bean sample infected by Bean golden yellow mosaic virus BGYMV (Lane 5) (B) (MW) contains a 500 bp DNA size marker, samples Sq142, Sq143, Sq150, Zu162, To166, Ch176, Es182, Sq185, Ch189, Ch201, Ch228, (Lane 1 - 11), negative control (Lane 12) and positive control a bean sample infected by BGYMV (Lane 13). 
Table 1. Percent nucleotide identity among sequences of the DNA-A bottom of isolates of Squash yellow mild mottle virus (SYMMoV)

\begin{tabular}{|c|c|c|c|c|c|c|c|c|c|}
\hline \multicolumn{2}{|c|}{ " GenBank Accession number } & ${ }^{1}$ Sample number & ${ }^{2} \mathrm{Sq} 142$ & Sq143 & Sq185 & $\mathrm{Sq} 229$ & ${ }^{3} \mathrm{Zu} 162$ & ${ }^{4}$ To 166 & ${ }^{5} \mathrm{Ch} 189$ \\
\hline \multicolumn{2}{|r|}{ AY064391 } & SYMMoV & 97 & 97 & 96 & 97 & 97 & 97 & 97 \\
\hline \multicolumn{2}{|r|}{ AF325497 } & MCLCuV-GT & 90 & 90 & 89 & 90 & 90 & 90 & 90 \\
\hline Family & Species & ${ }^{1}$ Sample number & ${ }^{2} \mathrm{Sq} 142$ & Sq143 & Sq185 & Sq229 & ${ }^{3} \mathrm{Zu} 162$ & ${ }^{4}$ To166 & ${ }^{5} \mathrm{Ch} 189$ \\
\hline \multirow{5}{*}{ Cucurbitaceae } & \multirow{4}{*}{ Cucurbita moschata } & $\mathrm{Sq} 142$ & ${ }^{6} \mathrm{ID}$ & - & - & - & - & - & - \\
\hline & & $\mathrm{Sq} 143$ & 99 & ID & - & - & - & - & - \\
\hline & & $\mathrm{Sq} 185$ & 98 & 98 & ID & - & - & - & - \\
\hline & & $\mathrm{Sq} 229$ & 98 & 99 & 97 & ID & - & - & - \\
\hline & Cucurbita pepo & Zu162 & 98 & 98 & 97 & 98 & ID & - & - \\
\hline \multirow{2}{*}{ Solanaceae } & Solanum lycopersicum & To166 & 99 & 99 & 98 & 99 & 99 & ID & - \\
\hline & Capsicum anпuит & Ch189 & 99 & 99 & 98 & 99 & 99 & 100 & ID \\
\hline
\end{tabular}

${ }^{1}$ Numbers represent the code for each of the positive samples, ${ }^{2} \mathrm{Sq}=$ Squash, ${ }^{3} \mathrm{Zu}=\mathrm{Zucchini},{ }^{4} \mathrm{To}=$ Tomato, ${ }^{5} \mathrm{Ch}=$ Pepper, ${ }^{6} \mathrm{ID}=100 \%$ identity

Table 2. Percent nucleotide identity among sequences of the DNA-A bottom of isolates of Pepper golden mosaic virus (PepGMV)

\begin{tabular}{|c|c|c|c|c|c|c|c|c|c|}
\hline \multicolumn{2}{|c|}{ GenBank Accession number } & ${ }^{1}$ Sample name & ${ }^{2} \mathrm{Ch} 176$ & Ch201 & Ch228 & ${ }^{3} \mathrm{Sq} 150$ & ${ }^{4}$ Es 182 & ${ }^{5}$ Cha4265 & ${ }^{6} \mathrm{Po} 3696$ \\
\hline \multicolumn{2}{|c|}{ AF149227 } & PepGMV-CR & 99 & 99 & 99 & 99 & 97 & 99 & 98 \\
\hline \multicolumn{2}{|c|}{ AY928516 } & PepGMV-Ser & 97 & 96 & 97 & 97 & 95 & 96 & 97 \\
\hline Family & Crop & ${ }^{1}$ Sample name & ${ }^{2} \mathrm{Ch} 176$ & Ch201 & Ch228 & ${ }^{3} \mathrm{Sq} 150$ & ${ }^{4}$ Es 182 & ${ }^{5}$ Cha4265 & ${ }^{6} \mathrm{Po} 3696$ \\
\hline \multirow{3}{*}{ Solanaceae } & \multirow{3}{*}{ Capsicum annuum } & Ch176 & ${ }^{7}$ ID & - & - & - & - & - & - \\
\hline & & Ch201 & 99 & ID & - & - & - & - & - \\
\hline & & Ch228 & 99 & 99 & ID & - & - & - & - \\
\hline \multirow{3}{*}{ Cucurbitaceae } & Cucurbita moschata & $\mathrm{Sq} 150$ & 99 & 99 & 99 & ID & - & - & - \\
\hline & Cucurbita pepo & Es182 & 97 & 97 & 98 & 98 & ID & - & - \\
\hline & Sechium edule & Cha4265 & 99 & 99 & 99 & 100 & 98 & ID & - \\
\hline Fabaceae & Erythrina spp. & Po3696 & 98 & 98 & 99 & 99 & 97 & 99 & ID \\
\hline
\end{tabular}

${ }^{1}$ Numbers represent the codes for each of the positive samples, ${ }^{2} \mathrm{Ch}=$ pepper, ${ }^{3} \mathrm{Sq}=$ squash, ${ }^{4} \mathrm{Es}=$ scallopini ${ }^{5} \mathrm{Cha}=\mathrm{Chayote},{ }^{6} \mathrm{Po}=$ Erythrina spp, ${ }^{7} \mathrm{ID}=100 \%$ identity

98\% similarity with PepGMV-CR (GenBank, AF149227) and 95\% PepGMV-YV (GenBank, AF063139).

Phylogenetic relationships among sequences corresponding to the DNA-A bottom region are shown in Fig. 2. Isolates from solanaceous plants (Ch189 and To166) and cucurbits (Sq142, Sq143, Sq185, Sq229 and Zu162) formed a well-defined group that was clearly related to the Costa Rican isolate of SYMMoV obtained by Karkashian et al. (2002). Isolates from cucurbits (Sq150, Es182, Cha4265), pepper (Ch176, Ch201, Ch228) and Erythrina sp. (Po3696) were grouped with isolates of PepGMV.

\section{Discussion}

Symptoms observed in the analyzed samples were similar to those previously described for plants infected with begomovirus (Hull, 2002) (Fig. 1). These viruses have caused negative effects on production in crops such as cotton, bean, tomato, pepper and cucurbits (Rojas et al.,
2005). Moreover, begomoviruses are considered to be agronomically important pathogens in Costa Rica (Hilje et al., 1993) and worldwide (Morales, 2010; Navas-Castillo et al., 2011; Rojas and Gilbertson, 2008). The percent of nucleotide identity among partial sequences of the SYMMoV isolates detected in this study was between 97 and 100\% (Table 1), indicating a low variability between them. Further more isolates and research are needed to confirm this observation. The phylogenetic relationships shown in Fig. 3 indicated that the partial sequence of the SYMMoV isolates obtained during this study are more closely related to MCLCuV-GT than to other begomoviruses infecting cucurbits. It has been considered that SYMMoV may be an isolate of MCLCuV (Brown et al., 2005). The sequence similarity for the DNA-A of the two viruses $(88.8 \%)$ is at the limit $89 \%$ defined by Fauquet et al. (2008) to distinguish between isolates of the same species. However, there are differences in symptoms, hosts range and sequence similarity in conserved regions to suggest that further 


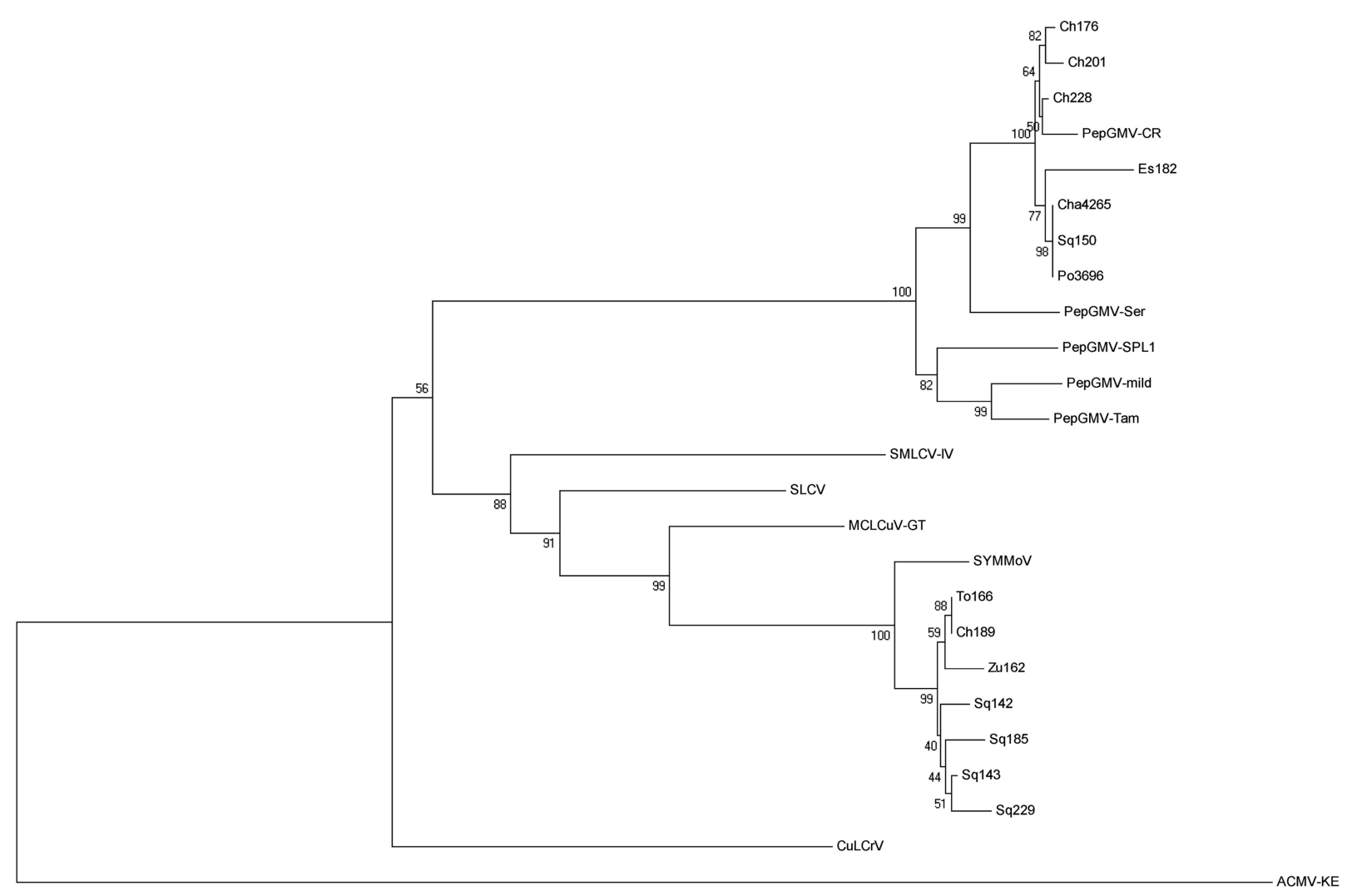

Fig. 3. Phylogenetic relationships established by neighbor-joining analysis based on partial sequences of DNA-A ( 1,100 bp) of begomovirus species shown in Table 3. Horizontal line length is proportional to the number of nucleotide differences at each branch. Bootstrap values for 1,000 replicates were used. African cassava mosaic virus (ACMV-[KE]) was used as an outgroup.

information is required to elucidate this case.

The symptoms described for MCLCuV-GT and SYMMoV are different. MCLCuV-GT produced severe leaf deformation and reduced fruit set in Cucumis melo (melon) (Brown et al., 2001b). While, SYMMoV caused no symptoms in the fruit (J. Karkashian, personal communication) and leaf chlorotic mottle are often mild in Carica papaya (papaya) and in cucurbits (Karkashian et al., 2002). Additionaly, MCLCuV-GT and SYMMoV also differ in their hosts range. The first report of MCLCuV-GT was in melon (Brown et al., 2001b) and there have since been other report in this crop (Jord et al., 2005). MCLCuV-GT experimentally infects Cucurbita maxima, C. pepo, Citrullus lanatus, Phaseolus vulgaris (bean), Nicotiana benthamiana and Datura stramonium (Idris et al., 2008). On the other hand, natural infections of SYMMoV have been detected not only in cucurbits but also in papaya (Karkashian et al., 2002) and more recently in bean (Karkashian et al., 2011). This is an uncommon characteristic for begomoviruses, which tend to have a narrow host range (Rojas et al., 2005). Moreover, MCLCuV-GT has not been found infecting tomato or pepper even under experimental conditions (Idris et al., 2008), whereas SYMMoV was detected in both solanaceaous crops in this study.

Regardless the sequence similarity of $88.8 \%$ between SYMMoV and MCLCuV-GT complete DNA-A, their association is less evident when only one region as the capsid protein gene is considered. According to Brown et al. (2011) sequence similarity among the capsid protein genes and the common region of the genomic components of these two viruses was less than $87 \%$. These differences were also observed with partial sequences of the capsid protein gene of two Nicaraguan isolates (GenBank, AJ8442150, AJ8442151) detected in Cucurbita argyrosperma (Ala-Poikela et al., 2005). Comparison of a $\sim 260 \mathrm{bp}$ sequence from the Nicaraguan isolates (GenBank, AJ842150, AJ842151) and partial sequences of isolate Sq142 (GenBank, JN408719) obtained in this study showed $94-98 \%$ nucleotide similarity with SYMMoV (GenBank, AY064391) and only $80-83 \%$ with MCLCuV-GT (GenBank, AF325497).

More biological data such as the ability to generate infectious reassortants, sap transmissibility and germplasm 
Table 3. Sequences of isolates of begomoviruses from this study, and other obtained from GenBank used in phylogenetic analysis

\begin{tabular}{|c|c|c|c|}
\hline Virus [isolate] & Acronym & Accession number & Sequence \\
\hline \multirow{7}{*}{ Pepper golden mosaic virus-[Costa Rica $]^{1}$} & Ch176 & JN592718 & \multirow{14}{*}{ DNA-A bottom region } \\
\hline & Ch201 & JN592719 & \\
\hline & Ch228 & JN592720 & \\
\hline & $\mathrm{Sq} 150$ & JN592721 & \\
\hline & Es 182 & JN609290 & \\
\hline & Cha4265 & JN609291 & \\
\hline & Po3696 & JN609292 & \\
\hline \multirow{7}{*}{ Squash yellow mild mottle virus ${ }^{1}$} & Sq142 & JN408719 & \\
\hline & Sq143 & JN408721 & \\
\hline & Sq185 & JN573299 & \\
\hline & $\mathrm{Sq} 229$ & JN592722 & \\
\hline & Zu162 & JN592715 & \\
\hline & To166 & JN592716 & \\
\hline & Ch189 & JN592717 & \\
\hline Pepper golden mosaic virus-[Costa Rica] & PepGMV-CR & AF149227 & \multirow{11}{*}{ Complete DNA-A } \\
\hline Pepper golden mosaic virus-[Mild tigre] & PepGMV-mild & EF210556 & \\
\hline Pepper golden mosaic virus-[Serrano] & PepGMV-SER & AY928516 & \\
\hline Pepper golden mosaic virus-[San Luis Potosi] & PepGMV-SPL1 & GU564594 & \\
\hline Pepper golden mosaic virus-[Tamaulipas] & PepGMV-Tam & U57457 & \\
\hline Squash yellow mild mottle virus & SYMMoV & AY064391 & \\
\hline Melon clorotic leaf curl virus-[Guatemala] & MCLCuV-GT & AF325497 & \\
\hline Squash mild leaf curl virus-Imperial Valley & SMLCV-IV & AF421552 & \\
\hline Squash leaf curl virus & SLCV & M38183 & \\
\hline Cucurbit leaf crumple virus & $\mathrm{CuLCrV}$ & NC002984 & \\
\hline African cassava mosaic virus-Kenya & ACMV-KE & J02057 & \\
\hline
\end{tabular}

${ }^{1}$ Isolates obtained in this study

susceptibility; will help to clarify the relationship of MCLCuV-GT and SYMMoV differences. There are previous examples for parallel evolution of new crop-infecting begomoviruses species in multiple locations, including bean golden mosaic disease (Gilbertson et al., 1993) and African cassava mosaic (Varma and Malathi, 2003). These discrepancies in host range, symptoms and sequence difference in conserved regions, may indicate that these are two related but distinct virus species or that these are two isolates from the same species with divergent evolution (Brown et al., 2011).

The percent of nucleotide identity among partial sequences of PepGMV from this study was high $(97-100 \%$, Table 2), in concordance with a previous study with PepGMV isolates from North America (Brown et al., 2005). It should be noted that the partial sequence of sample Es182 showed lower similarity ( $97 \%$ and $95 \%$ ) with the PepGMV-CR (GenBank, AF149227) and the PepGMV-Ser (GenBank, AY928516) than the other isolates of this study; however it is clearly an isolate of the same virus (Table 2). A close phylogenetic relationship (Fig. 3) was showed between samples in this study and the original Costa Rican PepGMV isolate obtained by Lotrakul et al. (2000) from Capsicum frutescens and $C$. chinense. There was also an association with other previously reported isolates of PepGMV from different geographic regions (Brown et al., 2005).

Diseases caused by PepGMV were previously reported in Costa Rica in pepper (Lotrakul et al., 2000) and tomato (Nakhla et al., 2005). Additionally, this virus has been detected in Cucurbita argyrosperma in Nicaragua (AlaPoikela et al., 2005) as well as in cucurbits in this study. However, this is the first report of a begomovirus (PepGMV) in Sechium edule (chayote) in the Western Hemisphere. Prior to the current study, Chayote mosaic tymovirus (ChMV; Bernal et al., 2000; Hord et al., 1997) was the only known virus infecting chayote in Costa Rica. Although yield losses associated with PepGMV in chayote in the country are not reported yet; a more detailed study of the incidence and distribution of the virus in chayote plantations is required to establish the potential threat of this begomovirus. This is specially important when Costa Rica is one of the main countries producing and exporting chayote to the United 
States, Canada, Central America and the Caribbean (Cadena-Iñiguez et al., 2007).

Indigenous begomoviruses in other regions of the world apparently move between cucurbits and solanaceous crops. This is the case of Tomato leaf curl virus-New Delhi (ToLCV-NDe) in India (Mandal et al., 2004; Phaneendra et al., 2012; Sohrab et al., 2003; 2013), Squash leaf curl Philippines virus (SLCPHV) in Taiwan (Tsai et al., 2011) and Tomato leaf curl Palampur virus (ToLCPMV) reported in Iran (Heydarnejad et al., 2012). Probably PepGMV occurrence in chayote report in this study is also another example of this phenomenon. Additionally, the Chayote yellow mosaic virus (ChaYMV, GenBank AJ223191) detected in chayote plantations in the southeast of India and Nigeria, emerged as a potential new begomovirus specie.

The detection of PepGMV in bean (Hilje et al., 1993) and Erythrina spp. suggest the ability of this virus to infect also Fabaceae species. Although Erythrina spp. is not a crop for human consumption, it is used as a living fence (Muschler and Bonnemann, 1997) and in agroecosystems using a silvopastoral system (Morton, 1994). Close association of Erythrina spp. with whitefly infested vegetable crops may facilitate the transmission of the virus to this species when crops are eliminated. Erythrina trees may also serve as hosts for the virus in between cropping seasons and reservoirs for infection of new fields.

The results discussed herein may be an example of the adaptation of begomoviruses to new hosts and environments. Further studies are needed to confirm this hypothesis. The emergence of new viral strains and species due to the adaptation of existing viruses is a worldwide process that occurs constantly over time (Anderson et al., 2004; Fargette et al., 2006; Jones, 2009; Rojas and Gilbertson, 2008; Navas-Castillo et al., 2011). Therefore, it is recommended to perform periodical molecular characterization of begomoviruses, in order to determine the relationships between preexisting begomoviruses species and their hosts, and to identify arising new isolates/species. A clear understanding of the factors determining the evolution of these viruses is of importance in order to avoid future economic losses and to avoid their dispersal to other regions and crops.

\section{Acknowledgments}

The authors thank Felipe Arauz Cavallini and Mauricio Montero Astua for comments on the manuscript, and the National Council for Scientific and Technological Research (CONICIT), the Ministry of Science and Technology (MICIT), the State Fund for Higher Education (FEES) and Universidad de Costa Rica for financial support for this project.

\section{References}

Ala-Poikela, M., Svensson, E., Rojas, A., Horko, T., Paulin, L. and Valkonen, J. P. T. 2005. Genetic diversity and mixed infections of begomoviruses infecting tomato, pepper and cucurbit crops in Nicaragua. Plant Pathol. 54:448-459.

Altschul, S. F., Gish, W., Miller, W., Myers, E. W. and Lipman, D. J. 1990. Basic local alignment search tool. J. Mol. Biol. 215:403-410.

Anderson, P. K., Cunningham, A. A., Patel, N. G., Morales, F. J., Epstein, P. R. and Daszak, P. 2004. Emerging infectious diseases of plants: pathogen pollution, climate change and agrotechnology drivers. Trends Ecol. Evol. 19:535-544.

Ascencio-Ibáñez, J. T., Díaz-Plaza, R., Méndez-Lozano, J., Monsalve-Fonnegra, Z. I., Arguello-Astorga, R. and Rivera-Bustamante, R. F. 1999. First report of Tomato yellow leaf curl geminivirus in Yucatan, Mexico. Plant Dis. 83:1178.

Bernal, J. J., Jiménez, I., Moreno, M., Hord, M., Rivera, C., Koenig, R. and Rodríguez-Cerezo, E. 2000. Chayote mosaic virus, a new tymovirus infecting Cucurbitaceae. Phytopathology 90:1098-1104.

Bezerra-Agasie, I. C., Ferreira, G. B., Avila, A. C. and InoueNagata, A. K. 2006. First report of Tomato severe rugose virus in chili pepper in Brazil. Plant Dis. 90:114.

Brown, J. K., Poulos, B. T. and Nelson, M. R. 1989. Two whitefly-transmitted geminiviruses isolated form pepper affected with tigr disease. Phytopathology 79:908.

Brown, J. K. and Poulos, B. T. 1990. Serrano golden mosaic virus: A newly identified whitefly-transmitted geminivirus of pepper and tomato in the United States and Mexico. Plant Dis. 74:720.

Brown, J. K., Bird, J. and Fletcher, D. C. 1993. First report of passiflora leaf mottle disease caused by a whitefly-transmitted geminivirus in Puerto Rico. Plant Dis. 77:1264.

Brown, J. K., Idris, A. M., Torres-Jerez, I., Banks, G. K. and Wyatt, S. D. 2001a. The core region of the coat protein gene is highly useful for establishing the provisional identification and classification of begomoviruses. Arch. Virol. 146:1581-1598.

Brown, J. K., Idris, A. M., Rogan, D., Hussein, M. H. and Palmieri, M. 2001b. Melon chlorotic leaf curl virus, a new begomovirus associated with Bemisia tabaci infestations in Guatemala. Plant Dis. 85:1027.

Brown, J. K., Idris, A. M., Ostrow, K. M., Goldberg, N., French, R. and Stenger, D. C. 2005. Genetic and phenotypic variation of the Pepper golden mosaic virus complex. Phytopathology 95:1217-1224.

Brown, J. K., Mills-Lujan, K. and Idris, A. M. 2011. Phylogenetic analysis of Melon chlorotic leaf curl virus from Guatemala: Another emergent species in the Squash leaf curl virus clade. Virus Res. 158:257-262.

Cadena-Iñiguez, J., Arévalo-Galarza, L., Avendaño-Arrazate1, C. H., Soto-Hernández, M., Ruiz-Posadas, L. M., Santiago-Osorio, E., Acosta-Ramos, M., Cisneros-Solano, V. M., AguirreMedina, J. F. and Ochoa-Martínez, D. 2007. Production, genetics, postharvest management and pharmacological characteristics of Sechium edule (Jacq.) Sw. Global Science Books. 
Fresh Produce 1:41-53.

Costa, A. S. and Bennett, C. W. 1950. Whitefly-transmitted mosaic of Euphorbia prunifolia. Phytopathology 40:266-283.

Costa, A. S. and Carvalho, A. M. 1960. Mechanical transmission and properties of the Abutilon mosaic virus. Phytopathol. $Z$. 37:250-272.

Dellaporta, S. L., Wood, J. and Hicks, J. B. 1983. A plant DNA minipreparation: version II. Plant Mol. Biol. Rep. 1:19-21.

Díaz, M., Maxwell, D. P., Karkashian, J. P. and Ramírez, P. 2002. Calopogonium golden mosaic virus identified in Phaseolus vulgaris from western and northern regions of Costa Rica. Plant Dis. 86:188.

Fire, A. and Xu, S.Q . 1995. Rolling replication of short DNA circles. Proc. Nat. Acad. Sci. USA 92:4641-4645.

Fargette, C., Konaté, G., Fauquet, C., Muller, E., Peterschmitt, M. and Thresh, J. M. 2006. Molecular ecology and emergence of tropical plant viruses. Annu. Rev. Phytopathol. 44:235-260.

Fauquet, C. M., Briddon, R. W., Brown, J. K., Moriones, E., Stanley, J., Zerbini, M. and Zhou, X. 2008. Geminivirus strain demarcation and nomenclature. Arch. Virol. 53:783-821.

Gámez, R. 1971. Los virus del frijol en Centroamérica. I. Transmisión por moscas blancas (Bemisia tabaci) y plantas hospedantes del virus del mosaico dorado. Turrialba 21:22-27.

Gilbertson, R. L., Hidayat, S. H., Martínez, R. T. and Maxwell, D. P. 1991. Differentiation of bean infecting geminivirus by nucleic acid hybridization probes and aspects of bean golden mosaic in Brazil. Plant Dis. 75:336-342.

Gilbertson, R. L., Faria, J. C., Ahlquist, P. G. and Maxwell, D. P. 1993. Genetic diversity in geminiviruses causing bean golden mosaic disease: the nucleotide sequence of the infectious cloned DNA components of a Brazilian isolate of bean golden mosaic virus. Phytopathology 83:709-715.

Heydarnejad, J., Hesari, M., Massumi, H. and Varsani, A. 2013. Incidence and natural hosts of Tomato leaf curl Palampur virus in Iran. Australas. Plant Pathol. 42:195-203.

Hilje, L., Lastra, R., Zoebisch, T., Calvo, G., Segura, L., Barrantes, L., Alpízar, D. and Amador, R. 1993. Las moscas blancas en Costa Rica. In: Las moscas blancas (Homoptera: Aleyrodidae) en América Central y el Caribe, ed. by L. Hilje and O. Arboleda, pp. 58-63. CATIE, Turrialba, Costa Rica..

Hord, M., Villalobos, W., Macaya-Lizano, A. V. and Rivera, C. 1997. Chayote mosaic, a new disease in Sechium edule caused by a tymovirus. Plant Dis. 81:374-378.

Hull, R. 2002. Matthews' Plant Virology. $4^{\text {th }}$ ed. New York. Academic Press.

Idris, A. M., Rivas-Platero, G., Torres-Jerez, I. and Brown, J. K. 1999. First report of Sinaloa tomato leaf curl geminivirus in Costa Rica. Plant Dis. 83:303.

Idris, A. M., Mills-Lujan, K., Martin, K. and Brown, J. K. 2008. Melon chlorotic leaf curl virus: Characterization and differential reassortment with closest relatives reveal adaptive virulence in the Squash leaf curl virus clade and host shifting by the host-restricted Bean calico mosaic virus. J. Virol. 82: 1959-1967.

Jones, R. A. C. 2009. Plant virus emergence and evolution: Origins, new encounter scenarios, factors driving emergence, effects of changing world conditions, and prospects for control. Virus Res. 141:113-130.

Jord, C., Font, M. I., Martínez-Culebra, P. and Tello, J. 2005. Viral etiology of diseases detected in melon in Guatemala. Plant Dis. 89:338.

Karkashian, J. P., Maxwell, D. P. and Ramírez, P. 2002. Squash yellow mottle geminivirus: a new cucurbit infecting geminivirus from Costa Rica. Phytopathology 92:125.

Karkashian, J. P., Ramos-Reynoso, E. D., Maxwell, D. P. and Ramírez, P. 2011. Begomoviruses associated with bean golden mosaic disease in Nicaragua. Plant Dis. 95:901-906.

Kimura, M. 1980. A simple method for estimating evolutionary rate of base substitution through comparative studies of nucleotide sequences. J. Mol. Evol. 16:111-120.

Kumar, S., Nei, M., Dudley, J. and Tamura, K. 2008. MEGA: A biologist-centric software for evolutionary analysis of DNA and protein sequences. Brief. Bioinform. 9:299-306.

Leal, R. A. and Quintero, S. 1989. Caracterización de una virosis del chile transmisible por mosquita blanca en la planicie Huasteca. Rev. Mex. Fitopatol. 7:147-149.

Lotrakul, P., Valverde, R. A., De La Torre, R., Jeonggu, S. and Gómez, A. 2000. Occurrence of a strain of Texas pepper virus in Tabasco and Habanero pepper in Costa Rica. Plant Dis. 84:168-172.

Mandal, B., Mandal, S., Sohrab, S. S., Pun, K. B. and Varma, A. 2004. A new yellow mosaic disease of chayote in India. Plant Pathol. 53:797.

Morales, F. J., Rivera-Bustamante, R. F., Salinas, R., TorresPacheco, I., Díaz-Plaza, R., Aviles, W. and Ramírez, G. 2005. Whiteflies as vectors of viruses in legume and vegetable mixed cropping systems in the tropical lowlands of Central America, Mexico and the Caribbean (short title for running header: vectors in mixed cropping systems of the neotropics). In: Whitefly and Whitefly-Borne Viruses in the Tropics: Building a Knowledge Base, ed. by P. K. Anderson and F. J. Morales, pp. 173-263. CIAT, Palmira, Colombia.

Morales, F. J. 2010. Distribution and dissemination of begomoviruses in Latin America and the Caribbean. In: Bemisia: Bionomics and Management of a Global Pest ed. by P. A. Stansly and S. E. Naranjo, pp 283-318. Springer Science, Netherlands.

Morton, J. F. 1994. Pito (Erythrina berteroana) and chipilin (Crotalaria longirostrata), (Fabaceae) two soporific vegetables of Central America. Econ. Bot. 48:130-138.

Muschler, R. G. and Bonnemann, A. 1997. Potentials and limitations of agroforestry for changing land-use in the tropics: experiences from Central America. Forest Ecol. Manag. 91:61-73.

Nakhla, M. K., Maxwell, M. D., Hidayat, S. H., Lange, D. R., Loniello, A. O., Rojas, M. R., Maxwell, D. P., Kitajima, E. W., Rojas, A., Anderson, P. and Gilbertson, R. L. 1994. Two geminiviruses associated with tomatoes in Central America. Phytopathology 84:1155.

Nakhla, M. K., Sorensen, A., Maxwell, D. P., Mejia, L., Ramírez, P. and Karkashian, J. P. 2005. Proc. $1^{\text {st }}$ IS on Tomato Diseases. In: Molecular characterization of tomato-infecting begomovi- 
ruses in Central America and development of DNA-based detection methods, ed. by M. T. Momol, P. Ji and J. B. Jones. Acta Hort. 695:277-288.

Navas-Castillo, J., Fiallo-Oliv, E. and Sánchez-Campos, S. 2011. Emerging virus diseases transmitted by whiteflies. Annu. Rev. Phytopathol. 49:219-248.

Nozaki, D. N., Krause-Sakate, R., Hasegawa, J. M., Cezar, M. A., Dziuba, P. H. and Pavan, M. A. 2006. First report of Tomato severe rugose virus infecting pepper plants in Brazil. Fitopatol. Bras. 31:321.

Phaneendra, C., Rao, K. R. S. S., Jain, R. K. and Mandal, B. 2012. Tomato leaf curl New Delhi virus is Associated With Pumpkin Leaf Curl: A New Disease in Northern India. Indian J. Virol. 23:42-45.

Quiñones, M., Fonseca, D., Accotto, G. P. and Martínez, Y. 2001. Viral infections associated with the presence of begomovirus in pepper plants in Cuba. Rev. Prot. Veg. 16:147-151.

Rojas, M. R., Gilbertson, R. L., Russel, D. and Maxwell, D. P. 1993. Use of degenerate initiators in the polymerase chain reaction to detect whitefly-transmitted geminiviruses. Plant Dis. 77:340-347.

Rojas, A., Kvarnheden, A. and Valkonen, J. P. T. 2000. Geminiviruses infecting tomato crops in Nicaragua. Plant Dis. 84:843846.

Rojas, A. 2005. A complex of begomoviruses affecting tomato crops in Nicaragua. Available at: http://pub.epsilon.slu.se/727/ 1/Agraria492.pdf. Accessed on July 02, 2011.

Rojas, M. R., Hagen, C., Lucas, W. J. and Gilbertson, R. L. 2005. Exploting chinks in the plant's armor: evolution and emergence of geminiviruses. Annu. Rev. Phytopathol. 43:361-394.

Rojas, M. R. and Gilbertson, R. L. 2008. Emerging plant viruses: a diversity of mechanisms and opportunities. In: Plant virus evolution, ed. by M. J. Roossinck, pp. 27-51. Springer-Verlag,
Berlin Heidelberg.

Sohrab, S. S., Mandal, B., Pant, R. P. and Varma, A. 2003. First Report of association of Tomato leaf curl virus-New Delhi with yellow mosaic disease of Luffa cylindrica in India. Plant Dis. 87:1148.

Sohrab, S. S., Karim, S., Abuzenadah, A. M., Chaudhary, A. G., Varma, A. and Mandal, B. 2013. Role of cucurbits in apical leaf curl disease of potato in Northern India. Arch. Phytopathology. Plant Protec. Available at: http://dx.doi.org/10.1080/ 03235408.2012.752168. Accessed on February 08, 2013.

Thompson, J. D., Higgins, D. G. and Gibson, T. J. 1994. Clustal W: improving the sensitivity of progressive multiple sequence alignment through sequence weighting, position-specific gap penalties and weight matrix choice. Nucleic Acids Res. 22:4673-4680.

Tsai, W. S., Hu, C. J., Shung, D. P., Lee, L. M., Wang, J. T. and Kenyon, L. 2011. First Report of Squash leaf curl Philippines virus infecting chayote (Sechium edule) in Taiwan. Plant Dis. 95:1197-1197.

Umaharan, P., Padidam, M., Phelps, R. H., Beachy, R. N. and Fauquet, C. M. 1998. Distribution and diversity of geminiviruses in Trinidad Tobago. Phytopathology 88:1262-1268.

Varma, A. and Malathi, V. G. 2003. Emerging geminivirus problems: a serious threat to crop production. Ann. Appl. Biol. 142:145-164.

Wyatt, S. D. and Brown, J. K. 1996. Detection of subgroup III geminivirus isolates in leaf extracts by degenerate primers and polymerase chain reaction. Phytopathology 86:1288-1293.

Zhou, X., Liu, Y., Calvert, L., Munoz, C., Otim-Nape, G. W., Robinson, D. J. and Harrison, B. D. 1997. Evidence that DNA-A of a geminivirus associated with severe cassava mosaic disease in Uganda has arisen by interspecific recombination. $J$. Gen. Virol. 78:2101-2111. 